\title{
POZIOM I KORELATY PRĘŻNOŚCI PSYCHICZNEJ STUDENTÓW WCZESNEJ EDUKACJI W WYBRANYCH UCZELNIACH W POLSCE ${ }^{1}$
}

\begin{abstract}
Streszczenie: Celem artykułu jest opisanie poziomu prężności psychicznej i jej korelatów charakteryzujących studentów pedagogiki przedszkolnej i wczesnoszkolnej kończących studia licencjackie lub magisterskie. Przeprowadzono badania empiryczne metodą sondażu diagnostycznego wśród 839 studentów z dziewięciu uczelni w Polsce. Zastosowano trzy narzędzia badacze: skalę Resilience Scale-14 (Wagnild), kwestionariusz WEMWBS (Tennant, Stewart-Brown) oraz skalę PSS-10 (Cohen, Kamarck, Mermelstein). Ustalono, że skala RS-14 jest rzetelnym narzędziem do pomiaru prężności ( $\alpha$ Cronbach $a=0,90)$. Analizy statystyczne wyników badań wykazały, że większość badanych studentów ( 51,8 proc.) prezentuje przeciętny poziom prężności psychicznej, a co trzeci student pedagogiki charakteryzuje się wysokim poziomem prężności. Prężność psychiczna jest pozytywnie związana $\mathrm{z}$ dobrostanem psychicznym studentów, a negatywnie z natężeniem stresu w życiu codziennym. Na podstawie analizy regresji hierarchicznej ustalono, że prężność psychiczna jest ważnym predyktorem dobrostanu psychicznego studentów (skoryg. $R^{2}=$ 0,482 ) i odczuwanego stresu (skoryg. $R^{2}=0,223$ ). Prężność psychiczna może być traktowana jako ważny zasób osobowy przyszłych nauczycieli wczesnej edukacji.
\end{abstract}

Słowa kluczowe: prężność psychiczna; dobrostan psychiczny; stres; student pedagogiki przedszkolnej i wczesnoszkolnej.

Pojęcie prężności psychicznej (resilience) po raz pierwszy pojawiło się w latach 50. XX wieku w trakcie badań prowadzonych przez Jeanne i Jacka Block nad osobowością młodzieży (Block, Kremen 1996). Wraz z rozwojem badań empirycznych i ustaleń teoretycznych w tym obszarze sposób konceptualizacji tego pojęcia ulegał ciągłemu rozwojowi (Garmezy 1971; Anthony 1974, Rutter 1979, za: Rutter 1993; Werner, Bierman, French 1971, za: Luthar i in. 2000). W języku polskim nie ustalono

* Dr Ewa Kulawska, Uniwersytet Kardynała Stefana Wyszyńskiego w Warszawie, Wydział Nauk Pedagogicznych; e-mail: e.kulawska@uksw.edu.pl.

1 Badania finansowane ze środków na badania statutowe UKSW, wg umowy PBNP-9/18. 
jednego terminu będącego odpowiednikiem angielskiego resilience. Stosuje się różne określenia: odporność (Opora 2008), sprężystość (Kaczmarek 2011; Szwajca 2014), rezyliencja (Junik 2011). Termin prężności osobowej po raz pierwszy został zastosowany w języku polskim przez Zenona Uchnasta (1997). W tym artykule będziemy posługiwać się terminem prężność psychiczna dla określenia angielskiego pojęcia resilience.

Nina Ogińska-Bulik i Zygfryd Juczyński (2008a, s. 42) definiują termin prężności psychicznej jako „mechanizm samoregulacji obejmujący zarówno elementy poznawcze, charakterystyczne dla przekonań i oczekiwań a dotyczące m.in. spostrzegania rzeczywistości w kategoriach wyzwania, a także własnych kompetencji, jak i emocjonalne, obejmujące afekt pozytywny i stabilność emocjonalną oraz behawioralne wyrażające się w poszukiwaniu nowych doświadczeń i podejmowaniu różnorodnych i skutecznych strategii radzenia sobie z problemami”. W takim ujęciu prężność jest przeciwieństwem osobowości stresowej (typu D), w której świat jest spostrzegany jako zagrożenie, czego skutkiem jest wysoki poziom lęku i wycofanie z kontaktów z innymi osobami (Ogińska-Bulik 2009).

Ogólnie badacze zgadzają się z tym, że prężność psychiczna oznacza proces pozytywnej adaptacji człowieka w sytuacjach niekorzystnych, stresowych, zagrażających osobie, będących wynikiem działania czynników traumatycznych, wewnętrznych lub zewnętrznych. Koncepcja prężności psychicznej (resilience) otworzyła obiecujący nurt badań, który przyczynia się do lepszego poznania psychospołecznych uwarunkowań pozytywnej adaptacji do wymagań środowiska. Konceptualizacja pojęcia prężności psychicznej jest bardzo szeroko analizowana i obejmuje czynniki biologiczne, poznawcze, interpersonalne oraz środowiskowe. W próbie określenia bardziej szczegółowego zakresu pojęcia prężności psychicznej istotne jest zwrócenie uwagi na wielowymiarowość tego konstruktu i różne podejścia w jego definiowaniu.

W pierwszym podejściu określa się prężność psychiczną jako właściwość, cechę osobowości, zasób wewnętrzny człowieka (Masten 2007; Fredricson 2001). Jest ona ujmowana jako względnie trwała cecha osobowości, która determinuje proces adaptacji do dynamicznie zmieniających się warunków życia. Osobowościowe aspekty prężności określił po raz pierwszy J. Block i zdefiniował je jako ego-resiliency. Block i Kremer (1996) definiują ego-resiliency jako zdolność do elastycznej i adekwatnej adaptacji do zewnętrznych i wewnętrznych stresorów oraz jako predyspozycję do odporności na emocje negatywne, która pozwala powracać do równowagi wewnętrznej. W takim ujęciu cecha prężności ujawnia się w codziennym życiu, a nie tylko w obliczu traumatycznych wydarzeń. Wspomniani autorzy zwracają uwagę na rolę pozytywnych emocji i umiejętności modulacji kontroli w dostosowywaniu się do środowiska i jego wymagań. Osoby o wysokim poziomie prężności psychicznej potrafią skutecznie radzić sobie z wyzwaniami codzienności, sytuacjami zaskakującymi, wymagającymi elastycznego reagowania. Ogińska-Bulik i Juczyński (2008b) wymienili szereg cech charakterystycznych dla tych osób, są to: bliskie, 
serdeczne kontakty interpersonalne, pewność siebie, spokojny sposób bycia, umiejętność kontroli emocji, wytrwałość w dążeniu do celów i ich urzeczywistnienie, niezależność, autonomia i stabilność wewnętrzna.

Drugie podejście zakłada rozumienie pojęcia prężności psychicznej jako procesu rozwojowego (Luthar i in. 2000). Prężność może być rozumiana jako dynamiczny, przystosowawczy proces, który może rozpocząć się w dowolnym momencie życia i polega na uaktywnieniu wewnętrznych i zewnętrznych zasobów w sytuacji konfrontacji osoby z niekorzystnymi warunkami zewnętrznymi (np. sytuacje życiowe, traumatyczne wydarzenia). Prowadzi on do poradzenia sobie z trudną sytuacją, zaadaptowania się do niej (Bonanno 2012; Southwick i in. 2014). Na gruncie polskim Ostaszewski rozumie prężność jako „wieloczynnikowy proces pozytywnej adaptacji w którym czynniki chroniące kompensują lub redukują wpływ czynników ryzyka" (2005, s. 2).

Przedstawiając krótki rys historyczny, inicjujący rozwój pojęcia resilience, należy zwrócić uwagę na to, że pierwsze prace empiryczne dotyczyły dorosłych osób ze schizofrenią, które pomimo ciężkiej choroby były w stanie odpowiedzialnie podejmować pracę, zakładać rodziny i funkcjonować w społeczeństwie (Garmezy 1970). Kontynuacja tych prac objęła grupę dzieci wychowywanych przez matki ze schizofrenią, które ze względu na swoją chorobę nie były w stanie zapewnić dzieciom odpowiednich warunków rozwojowych, a mimo to dzieci rozwijały się prawidłowo. Wyniki badań skłoniły naukowców do poszukiwania indywidualnych właściwości, które mogą być odpowiedzialne za prawidłowy rozwój części badanej grupy dzieci, pomimo życia w warunkach wysokiego ryzyka (Garmezy, Streitman 1974). Kolejne, przełomowe, klasyczne już badania dzieci mieszkających na Hawajach, prowadzone przez Emmę Werner (Werner 1971, za: Luthar i in. 200o), zapoczątkowały szereg eksploracji badawczych w różnych kontekstach społeczno-ekonomicznych, środowiskach defaworyzowanych i związanych z ryzykiem rozwojowym. Badania prowadzono w odniesieniu do dzieci maltretowanych (Cicchetti, Rogosch 1997), żyjących w warunkach ubóstwa i przemocy środowiskowej (Richters, Martinez 1993), przewlekle chorych (Wells, Schwebel 1987), doświadczających traumatycznych wydarzeń życiowych (O’Dougherty-Wright i in. 1997). Początkowo szczególny nacisk $\mathrm{w}$ tych badaniach położono na poszukiwaniu czynników ochronnych (protective factors), które różnicują dzieci o pozytywnej adaptacji od tych słabiej przystosowanych do wymagań środowiska szkolnego i rodzinnego. Te badania koncentrowały się w trzech obszarach: (1) ustaleniu cech osobowościowych „dzieci odpornych”, takich jak: autonomia, wysokie poczucie własnej wartości, optymizm, skuteczność (Masten i in. 1988); (2) własności funkcjonowania rodziny dziecka, a także (3) cech szerszego środowiska społecznego. W ostatnich latach można zauważyć przesunięcie zainteresowań badaczy z wyszczególniania cech dziecka, rodziny czy środowiska na próbę zrozumienia, jaki mechanizm i konstelacja czynników są odpowiedzialne za prawidłowe funkcjonowanie człowieka pomimo niesprzyjających warunków i występowania czynników ryzyka, a także leżą u podstaw takiego funkcjonowania. 
Pojęcie prężności psychicznej, rozwinięte w obszarze badań nad dziećmi i młodzieżą, zostało zaadaptowane i zweryfikowane empirycznie także wśród osób dorosłych w zakresie zdrowia, funkcjonowania psychologiczno-społecznego oraz aktywności zawodowej. Prowadzono badania w odniesieniu do osób starszych (Alex, Lundman 2011; Callegari i in. 2016a; Cosco i in. 2016; Leppert i in. 2005; Ogińska-Bulik i in. 2015; Resnick, Inguito 2011), osób przewlekle chorych (Armando $i$ in 2010; Andrade i in. 2013; Cohen i in. 2014; Gheshlagh i in. 2016; Hofer i in. 2016; Ogińska-Bulik 2010b), osób uzależnionych od alkoholu (Ogińska-Bulik, 2014), młodych dorosłych na progu kariery zawodowej (Elbum i in 2016; Eley i in. 2013; Ogińska-Bulik, Zadworna-Cieślak 2014). Podsumowując wyniki badań wśród różnych grup społecznych, stwierdzono, że prężność psychiczna jest pozytywnie związana z dobrostanem psychicznym (well-being), ogólną jakością życia, poczuciem własnej wartości, wsparciem społecznym i subiektywną oceną zdrowia (Tempski i in. 2015; Wagnild 2009). Zauważono również negatywny związek pomiędzy prężnością psychiczną a depresją, stresem, lękiem, zaburzeniami związanymi z traumą, samotnością i poczuciem beznadziejności (Damasio i in. 2011; Nishi i in. 2010; Wagnild 2009). Powyższe ustalenia empiryczne skłaniają do konstatacji, że prężność psychiczna jest ważnym predyktorem funkcjonowania człowieka w kontekście rozwoju indywidualnego i społecznego.

\section{Prężność psychiczna nauczycieli w świetle badań}

Wymiar prężności psychicznej (resilience) może mieć duże znaczenie w rozwoju kariery zawodowej nauczycieli, którzy w swojej pracy mają ciągły kontakt z sytuacjami trudnymi, stresowymi, wymagającymi szybkiej i adekwatnej reakcji. Badania wskazują, że grupa zawodowa nauczycieli podlega znacznym obciążeniom psychospołecznym, których skutkiem może być wysoki poziom stresu, wypalenie zawodowe i mobbing w miejscu pracy (Terelak i in. 2007; Tucholska 2003; Sęk 2004; Mościcka-Teske 2014). Wysoki poziom prężności psychicznej pozwala osobie na skuteczne radzenie sobie ze stresem, trudnymi sytuacjami życia codziennego oraz negatywnymi emocjami. Ułatwia mobilizację do podejmowania działań naprawczych, zwiększa tolerancję na przykre wydarzenia generujące negatywne emocje i niepowodzenia życiowe. Osoba „prężna” charakteryzuje się stabilnością emocjonalną, a trudności, z którymi się styka w życiu, spostrzega jako wyzwanie i szansę na rozwój osobisty (Ogińska-Bulik, Juczyński 2008b; Ogińska-Bulik \& Kobylarczyk 2015).

Szczególnie stabilność emocjonalna i umiejętność zarządzania własnymi emocjami wydaje się być kluczowa w pracy nauczyciela z dziećmi. Równie ważna jest poznawcza ocena rzeczywistości szkolnej przez nauczyciela, a ponadto własnego działania edukacyjnego i wychowawczego, jak i umiejętność adekwatnego zachowania $\mathrm{w}$ relacjach $\mathrm{z}$ uczniami, innymi nauczycielami i rodzicami. W tym obszarze aktywności nauczycielskiej zdolność do prezentowania wysokiej prężności 
może być istotnym wymiarem zadowolenia z pracy i ogólnej oceny jakości życia. Nauczyciele o wysokiej prężności psychicznej mogą lepiej, bardziej efektywnie dawać sobie radę z codziennymi sytuacjami stresowymi, ponieważ z prężnością psychiczną związane są pozytywne emocje, które z kolei sprzyjają koncentracji osoby na zadaniu i spostrzeganiu pozytywnych stron danej sytuacji. Ogińska-Bulik (2011) wykazała w badaniach empirycznych, że kategoria prężności może różnicować osoby dorosłe pod względem wypalenia zawodowego. Szczególnie kobiety o wysokim poziomie prężności rzadziej doświadczają emocjonalnego wyczerpania i problemów związanych $\mathrm{z}$ funkcjonowaniem psychofizycznym w pracy.

W literaturze przedmiotu niewiele jest badań empirycznych dotyczących zasobów resilience wśród nauczycieli. Stanford (2001) ustalił w badaniach jakościowych, że nauczyciele z wysokim poziomem prężności czerpali głęboką osobistą satysfakcję ze swojej pracy, polegając na rozległej sieci wsparcia z udziałem innych nauczycieli, rodziny i przyjaciół oraz grup kościelnych. W badaniach Williams (2003) okazało się, że 12 doświadczonych nauczycieli w swoim badaniu czerpało siłę z radości i satysfakcji nauczania, a także starało się doskonalić poprzez rozwój zawodowy. Gu i Day (2007), w oparciu o badanie 300 doświadczonych nauczycieli w Anglii, zidentyfikowali trzy scenariusze/ścieżki, które opisują, w jaki sposób nauczyciele (1) kształtują swoją tożsamość osobistą; (2) oceniają sytuacje szkolne oraz (3) rozwijają wartości zawodowe i przekonania w trakcie swojej kariery nauczycielskiej. W pierwszym scenariuszu prężny nauczyciel znajdował równowagę między tymi trzema komponentami, przystosowując się optymalnie do sytuacji szkolnych. W dwóch pozostałych scenariuszach jeden lub więcej z tych trzech elementów stał się dominujący i nauczyciele znajdowali się w stanie nierównowagi.

Patterson, Collins i Abbott (2004) zdefiniowali prężność nauczycieli jako „produktywne wykorzystywanie energii do osiągania celów szkolnych w obliczu negatywnych warunków" (s. 3). W ich badaniu ośmiu doświadczonych nauczycieli zidentyfikowało mocne strony i strategie, które stosowali w sytuacjach trudnych, a dotyczyły one: podejmowania decyzji, dążenia do rozwoju zawodowego, rozwiązywania problemów, kontaktów z przyjaciółmi i współpracownikami oraz wykazywaniu się elastycznością w obliczu trudnych sytuacji. Głównym wyróżnionym czynnikiem w tych badaniach jest orientacja strategiczna polegająca na wierze i zaufaniu człowieka we własne siły i możliwości, służące pokonywaniu trudności oraz w zdolność wpływania na swoje życie i otoczenie. W ramach tego badania potwierdzono przekonanie, że prężność nauczycieli jako aktywnych podmiotów, przyjmujących różne strategie, pomaga znaleźć równowagę w obliczu przeciwności, nawet w sytuacjach, gdy posiadają oni minimalne zasoby wewnętrzne i borykają się z trudnymi warunkami pracy. Drugi wniosek z badań odnosi się do konstatacji, że wszyscy nauczyciele stosują różne strategie adaptacyjne, przynoszące odmienne skutki dla uczniów, rodziców i samych nauczycieli.

Badania prowadzone przez Ogińską-Bulik (2011) pokreśliły znaczenie prężności psychicznej jako czynnika chroniącego przed negatywnymi skutkami stresu 
zawodowego. Zawód nauczyciela należy do szczególnie stresowej profesji, a do głównych źródeł stresu, na podstawie badań Zubrzyckiej-Maciąg (2013), przeprowadzonych wśród nauczycieli z 97 szkół, można zaliczyć: trudności dydaktyczne, niepożądane zachowania uczniów, poczucie osamotnienia w działaniach zawodowych, pracę w trudnych warunkach. $Z$ badanej grupy 354 nauczycielek ze szkół podstawowych i gimnazjalnych z woj. lubelskiego, w latach 2011-2012, 80 proc. z nich odczuwało stres zawodowy na poziomie wysokim. Te z nich, które koncentrowały się na negatywnych emocjach, doświadczały wyższego poziomu stresu niż nauczycielki, które koncentrowały się na zadaniu. Z kolei badania Kaura (2017), przeprowadzone w szkołach indyjskich, państwowych i prywatnych, wskazały na pozytywny związek między prężnością psychiczną a osiągnięciami zawodowymi nauczycieli oraz negatywny związek, związany z emocjonalnym wyczerpaniem i depersonalizacją. Prężność psychiczna okazała się istotnym predyktorem wypalenia w zawodzie nauczyciela. Powyższe rozważania są podstawą do podjęcia badań własnych w zakresie prężności psychicznej wśród studentów przygotowujących się do zawodu nauczycielskiego.

\section{Cel, metoda i procedura badań własnych}

Celem prezentowanego artykułu jest, po pierwsze, empiryczna weryfikacja poziomu prężności psychicznej studentów ostatniego roku studiów kierunku pedagogika przedszkolna i wczesnoszkolna, którzy zamierzają podjąć pracę w zawodzie nauczyciela. Drugim celem jest określenie związku między prężnością psychiczną, stresem i dobrostanem psychicznym w ocenie studentów pedagogiki. W badaniach zastosowano metodę sondażu diagnostycznego, technikę ankiety, z wykorzystaniem trzech narzędzi badawczych.

W celu pomiaru poziomu prężności psychicznej przyszłych nauczycieli edukacji przedszkolnej i wczesnoszkolnej zastosowano narzędzie Resilience Scale-14 autorstwa Gail Wagnild (2009), będące skróconą wersją oryginalnej skali RS-25 (Wagnild, Young 1993). Surzykiewicz, Konaszewski i Wagnild (2019) wykonali walidację psychometryczną skali RS-14 w warunkach polskich wśród 2,715 osób w wieku 13-27 lat, głównie wśród kobiet (69,09 proc.). W badanej grupie było 400 uczniów w wieku 13-17 lat, 1659 studentów w wieku 19-27 lat (większość stanowiły kobiety - 82,3 proc.) i 656 osób w wieku 13-18 lat, nieprzystosowanych społecznie, przebywających w młodzieżowych ośrodkach socjoterapeutycznych i wychowawczych (MOS i MOW). Analiza rzetelności skali RS-14 w grupie studentów wskazuje na bardzo dobre własności psychometryczne narzędzia (współczynnik a Cronbacha wyniósł o,87). W procesie analizy psychometrycznej skali uzyskano potwierdzenie, że polska wersja skali RS-14 składa się z jednego czynnika, podobnie jak anglojęzyczny oryginał opracowany przez Wagnild (2009). Skala RS-14 została skonstruowana do pomiaru indywidualnego poziomu prężności psychicznej rozumianej jako relatywnie stabilny zasób człowieka. W tym ujęciu prężność jest pozytywną cechą 
osobowości, która może być aktywowana jako kompetencja osobista w procesie adaptacji w różnych sytuacjach życiowych. Skala RS-14 składa się z 14 twierdzeń odnoszących się do kategorii: znaczenie i cel życia (zdania 2, 9, 13), wytrwałość (zdania 6, 8), spokój umysłu (zdania 3, 10), samodzielność (zdania 1, 5, 7, 12, 14), egzystencjalna samotność (zdania 4, 11) (Wagnild, 2009). Respondenci udzielali odpowiedzi w siedmiostopniowej skali, punktowanej od 1 - zdecydowanie nie zgadzam się/twierdzenie jest całkowicie nietrafne aż do 7 - zdecydowanie zgadzam się/stwierdzenie jest całkowicie trafne. Po zsumowaniu punktów mogli uzyskać od 14 do 98 punktów. Wynik poniżej 64 punktów świadczył o niskiej prężności psychicznej, od 65 do 81 wskazywał na przeciętną prężność psychiczną, a powyżej 82 punktów - na wysoką prężność. Skala RS-14 została przetłumaczona na wiele języków, takich jak: arabski, grecki, rosyjski, hiszpański, szwedzki, fiński, norweski, chiński, japoński, koreański i jest stosowana na całym świecie.

Drugim zastosowanym narzędziem badawczym jest skala WEMWBS (Warwick-Edinburgh Mental Well-Being Scale, Clarke i in. 2011), służąca do oceny jakości życia studentów pedagogiki przedszkolnej i wczesnoszkolnej. Skala składa się z 14 stwierdzeń opisujących pozytywne odczucia (afekty), takie jak: optymizm, zadowolenie, radość, odprężenie oraz satysfakcjonujące relacje interpersonalne i pozytywne funkcjonowanie (energia do działania, samoakceptacja, autonomia, rozwój osobisty, poczucie bycia kompetentnym). Osoby badane są proszone o zaznaczenie odpowiedzi, która najlepiej opisuje ich odczucia z ostatnich dwóch tygodni na pięciostopniowej skali (1- nigdy; 2 - rzadko; 3 - czasami; 4 - często; 5 - zawsze). Każdej z odpowiedzi przypisano liczbę od 1 do 5, minimalna liczba punktów do zdobycia wynosiła 14, maksymalna - 70. Wyższa liczba zdobytych punktów oznaczała wyższy poziom dobrostanu psychicznego (Kulawska 2019). W prezentowanych badaniach własnych wśród 839 polskich studentów pedagogiki z wybranych uczelni współczynnik a Cronbacha dla skali WEMWBS wyniósł $\alpha=$ o,86, co świadczy o wysokiej rzetelności zastosowanego narzędzia.

Ponadto użyto również w badaniach skali PSS-10 (Psychological Stress Scale „Skala Odczuwanego Stresu”, autorzy: S. Cohena, T. Kamarck, R. Mermelstein) w adaptacji Z. Juczyńskiego i N. Ogińskiej-Bulik), która posłużyła do oceny subiektywnych odczuć związanych ze stresem (zawiera 1o pytań). Badany może uzyskać wynik od o do 40 punktów. Wynik w przedziale o-13 punktów oznacza niski poziom postrzeganego stresu, 14-19 punktów - przeciętny poziom postrzeganego stresu, a 20-40 punktów - wysoki poziom stresu. Respondenci udzielają odpowiedzi na pięciostopniowej skali (nigdy, prawie nigdy, czasem, dość często, bardzo często). Skala PSS-10 jest popularnym narzędziem w badaniach empirycznych i została przetłumaczona na 25 języków oraz adaptowana do różnych warunków społeczno-kulturowych. W naszych badaniach prowadzonych wśród studentów pedagogiki współczynnik a Cronbacha jest wysoki i wynosi $\alpha=0,86$.

Zastosowano procedurę doboru celowego, a kryteriami włączenia osób do badań zostali objęci studenci pedagogiki przedszkolnej i wczesnoszkolnej, studiów 
stacjonarnych lub niestacjonarnych kończący studia licencjackie lub magisterskie. Uczestnictwo w badaniu było dobrowolne i anonimowe. Uwzględniając powyższe kryteria, w badaniach uczestniczyło 839 studentów studiujących na następujących uczelniach: Uniwersytet Kardynała Stefana Wyszyńskiego w Warszawie (122 osoby), Uniwersytet Pedagogiczny w Krakowie (84 osoby), Uniwersytet Szczeciński (99 osób), Uniwersytet Śląski w Katowicach, filia w Cieszynie (107 osób), Uniwersytet w Białymstoku (96 osób), Uniwersytet Łódzki (100 osób), Akademia Ignatianum w Krakowie (59 osób), Akademia Pedagogiki Specjalnej im. Marii Grzegorzewskiej w Warszawie (75 osób), Uniwersytet Opolski (97 osób). Materiał empiryczny został zebrany w 2019 roku.

\section{Analiza wyników badań}

W badaniach wzięło udział, jak wspomniano wyżej, 839 studentów kierunku pedagogika o specjalności edukacja przedszkolna i wczesnoszkolna, w tym 821 kobiet i dziewięciu mężczyzn (dziewięć osób nie podało informacji o płci), 606 z nich jest studentami studiów licencjackich, a 230 respondentów kończy studia magisterskie. Większość studentów (513 osób) studiuje na studiach stacjonarnych, 321 osoby kształci się na studiach niestacjonarnych (pięć osób nie podało na ten temat informacji). Wiek badanych wynosi od 21 lat do 51, średnia wieku badanych wynosi: $M=24,61 ; S D=4,23$.

Studenci odpowiedzieli na pytanie dotyczące miejsca zamieszkiwania w czasie edukacji szkolnej. Wyniki badań wskazują, że większość (47,4 proc.) przyszłych nauczycieli wczesnej edukacji pochodzi ze środowiska wiejskiego, około 13 proc. wychowywało się w małych miastach liczących do 20 tys. mieszkańców, kolejne 27,7 proc. studentów uczęszczało do szkół w średnich i w dużych miastach do 500 tys. mieszkańców, a 11,2 proc. pochodzi z dużych aglomeracji w Polsce.

Pomiar prężności psychicznej przy użyciu skali RS-14 wskazuje na dobre własności psychometryczne, współczynnik $\alpha$ Cronbacha wynosi $\alpha=0,90$ i potwierdza wysoką rzetelność narzędzia; jest analogiczny do współczynnika uzyskanego w badaniach polskich Surzykiewicza i in. (2019), w badaniach fińskich $\alpha=0,87$ (Losoi $\mathrm{i}$ in. (2013); japońskich $\alpha=0,88$ (Nishi i in. 2010) i włoskich $\boldsymbol{\alpha}=0,88$ (Callegari $\mathrm{i}$ in. 2016b). W badanej grupie studentów pedagogiki wczesnej edukacji rozkład wyników prężności psychicznej wahał się od 32 do 98 punktów, a średnia dla całej grupy wynosi $M=74,39 ; S D=11,5$. Dla porównania w badaniach fińskich 243 osób (Losoi i in. 2013), z użyciem skali RS-14, uzyskano wyższą średnią $(M=76,3 ; S D$ $=10,7), \mathrm{z}$ kolei $\mathrm{w}$ badaniach japońskich przeprowadzonych wśród 430 studentów pielęgniarstwa i psychologii średnia była znacznie niższa: $M=63,78 ; S D=13,03$ (Nishi i in. 2010). W grupie 150 studentów Uniwersytetu Insubria we Włoszech średnia prężności psychicznej wynosiła: $M=76,13 ; S D=10,48$ (Callegari i in. 2016b) i była wyższa niż wśród badanych studentów polskich. 
Uwzględniając wskazane w opisie narzędzia, określające kategorie/poziomy prężności psychicznej (niską, średnią i wysoką), stwierdzamy, że studenci pedagogiki mieszczą się w zakresie tej własności w przedziale wyników średnich. Na wykresie nr 1 przedstawiono rozkład kategorii prężności psychicznej w badanej grupie studentów. Niska kategoria prężności psychicznej dotyczy 17,3 proc. studentów, średnia charakteryzuje 51,8 proc., a co trzeci student (30,9 proc.) opisuje siebie jako osobę charakteryzującą się wysoką prężnością psychiczną. Na podstawie jednoczynnikowej analizy wariancji ustalono, że te trzy grupy studentów różnią się istotnie w zakresie natężenia prężności psychicznej. I tak średnia arytmetyczna dla grupy o niskiej prężności wynosi: $M=56,25 ; S D=7,22$, w grupie o przeciętnej prężności: $M=73,03 ; S D=4,63$, a w grupie o wysokiej prężności średnia wynosi: $M=86,83 ; S D=4,65$. Test różnic średnich i testy post-hoc okazały się istotne statystycznie, co oznacza, że między tymi trzema grupami zachodzą wyraźne różnice, istotne statystycznie w zakresie prężności psychicznej $(F(2,774)=1574,55 ; p<0,001)$.

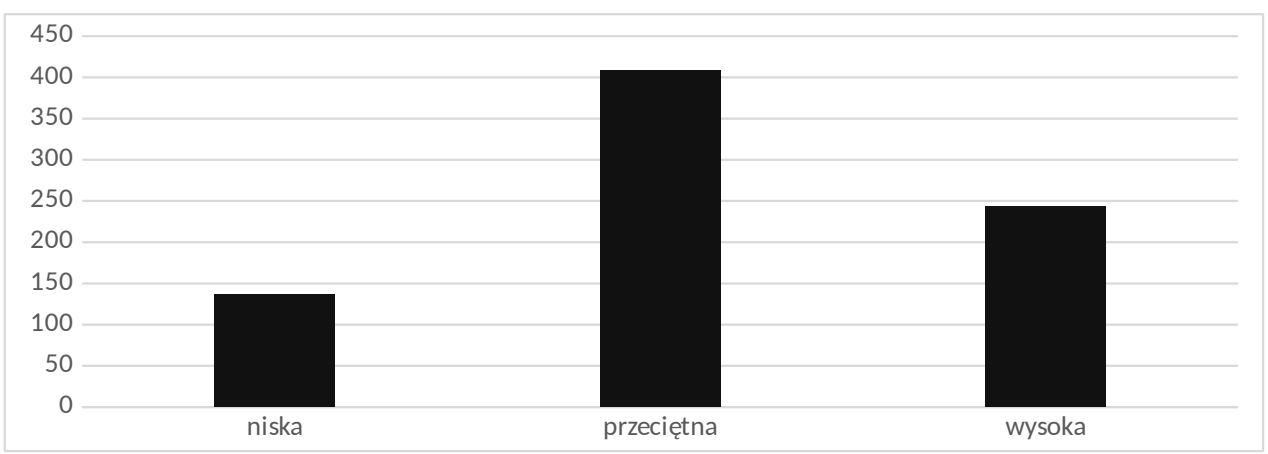

Wykres nr 1. Rozkład kategorii prężności psychicznej w badanej grupie studentów $(N=787)$

Źródło: opracowanie własne.

Materiał empiryczny, zebrany na 9. uczelniach wyższych w Polsce, pozwala na poszukiwanie odpowiedzi na pytanie, czy studenci różnią się w zakresie prężności psychicznej w zależności od miejsca studiowania. W tym celu przeprowadzono jednoczynnikową analizę wariancji, na podstawie której stwierdzamy, że studenci jednej z polskich uczelni akademickich uzyskali najniższe wyniki $(M=71,63 ; S D=$ $12,61)$, a studenci innego uniwersytetu najwyższe wyniki $(M=77,46 ; S D=9,68)$ w zakresie prężności psychicznej, i jest to różnica istotna statystycznie $(F(8,778)$ $=2,18 ; p<0,05)$. Studenci z pozostałych 7 . uczelni uzyskali wyniki zbliżone do średniej dla całej badanej grupy.

Ponadto jednoczynnikowa analiza wariancji wskazuje na to, że takie zmienne socjodemograficzne, jak miejsce zamieszkania i dochody przypadające na jednego członka w rodzinie studenta oraz subiektywna ocena dotycząca środków 
finansowych pozostających do dyspozycji studenta nie mają związku z poziomem prężności psychicznej. Z kolei okazało się, że studenci o zróżnicowanej średniej ocen na studiach różnią się poziomem prężności psychicznej. Studenci $(N=7)$ o średniej ocen poniżej 3,5 uzyskali najniższą średnią prężności $(M=64,00$; $S D=$ 16,03), ci z nich $(N=192)$, którzy mają średnią ocen na studiach miedzy 3,5 a 4, posiadają wyższą prężność $(M=73,5 ; S D=12,17)$. Średnia ocen mieszcząca się między 4 a 4,5 charakteryzuje studentów $(N=390)$ o średniej prężności $(M=74,09 ; S D=$ $11,36)$. Natomiast studenci $(N=185)$, którzy uzyskują średnie ocen powyżej 4,5 , oceniają siebie jako osoby o najwyższym poziomie prężności $(M=76,37 ; S D=10,51)$. Jednoczynnikowa analiza wariancji wykazała, że między tymi grupami studentów zachodzą różnice istotne statystycznie $(F(3,770)=4,23 ; p<0,01)$. Stwierdzamy, że prężność psychiczna jako zasób osobowy jest związana $z$ funkcjonowaniem osób młodych dorosłych również $\mathrm{w}$ zakresie radzenia sobie $\mathrm{z}$ obowiązkami studenta pedagogiki, organizacją pracy własnej i wyzwaniami intelektualnymi w procesie studiowania.

Interesującym aspektem badań jest próba odpowiedzi na pytanie, czy istnieje związek pomiędzy stresem a prężnością psychiczną w doświadczeniach studentów. W tym celu podzielono studentów na trzy grupy różniące się poziomem odczuwanego stresu. Najwięcej studentów $(N=471)$, ok. 57,3 proc., należy do grupy o wysokim natężeniu doświadczanego stresu, ok. 30 proc. $(N=244)$ - do grupy o przeciętnym stresie, a 12,7 proc. $(N=106)$ badanych studentów wskazało na niskie nasilenie stresu w życiu codziennym. Średnia arytmetyczna stresu rozumianego jako subiektywne odczucie dla całej grupy wynosi $M=20,29$; odchylenie standardowe $S D=5,99$. W pierwszej grupie o niskim natężeniu stresu średnia arytmetyczna wynosi $M=10,29 ; S D=2,96$, w grupie o przeciętnym natężeniu stresu $M=16,76 ; S D=1,78$, a w grupie o wysokim poziomie stresu $M=24,37 ; S D=3,67$. Różnice między tymi średnimi są istotne statystycznie i test $\mathrm{F} w$ analizie wariancji przybiera następujące wartości: $F(2,818)=1097 ; p<0,001)$. Przeprowadzone porównania post-hoc za pomocą testów Tukey'a HSD, Bronferroniego i Gamesa-Howella ujawniły istotne różnice $(p<0,001)$ między tymi trzema grupami. Kolejnym krokiem w analizie wyników badań jest poszukiwanie odpowiedzi na pytanie, czy doświadczanie stresu o różnym natężeniu pozostaje w związku z prężnością psychiczną. W celu przetestowania hipotezy o wpływie stresu (na trzech poziomach) na natężenie prężności psychicznej przeprowadzono jednoczynnikową analizę wariancji w planie dla grup niezależnych. Okazało się, że studenci o niskim natężeniu stresu charakteryzują siebie jako osoby o wysokiej prężności psychicznej $(M=83,06 ; S D=9,03)$, osoby wskazujące na przeżywanie stresu w przeciętnym zakresie uzyskały niższe wskaźniki prężności psychicznej $(M=77,66$; $S D=9,11)$, a studenci, którzy opisują swoje życie jako wysoce stresujące, dysponują mniejszymi zasobami prężności psychicznej $(M=70.90 ; S D=11,53)$. W wyniku analiz ustalono istotny statystycznie efekt zmiennej - stres $(F(2,769)=69,77 ; p<0,001)$. Konkluzja z powyższych wyników jest następująca: wraz ze wzrostem natężenia odczuwanego 
stresu następuje spadek prężności psychicznej. Oczywiście możemy też stwierdzić, że studenci, którzy charakteryzują się wyższym poziomem prężności psychicznej, lepiej radzą sobie z sytuacjami stresowymi.

Kolejnym krokiem jest ustalenie, czy prężność psychiczna może być predyktorem odczuwanego stresu przez studentów pedagogiki. W tym celu wykonano analizę regresji liniowej, w której zmienną zależną (wyjaśnianą) jest stres, a zmienną wyjaśniającą (predyktorem) jest prężność psychiczna. Zaproponowany model jest dobrze dopasowany do danych $(F(1,770)=223,84 ; p<0,001)$. Współczynniki regresji wskazują na to, że prężność psychiczna jest negatywnie związana z odczuwanym stresem $(\beta=-0,474 ; p<0,001)$. Wynik ten interpretujemy następująco: wraz ze wzrostem prężności psychicznej następuje spadek odczuwanego stresu. Testowany model wyjaśnia 22 proc. zmienności wariancji odczuwanego stresu (skoryg. $R^{2}=$ $0,223)$.

Z koncepcji i badań empirycznych nad prężnością psychiczną wynika, że ma ona ścisły związek z jakością życia i dobrostanem psychicznym (well-being). Jeśli człowiek potrafi poradzić sobie z trudnymi sytuacjami stresowymi, przystosować się do wymagań środowiskowych i zachować równowagę wewnętrzną, to jego poczucie jakości życia jest satysfakcjonujące. Ta teza znajduje odzwierciedlenie w wynikach badań własnych. Poziom prężności psychicznej ma związek z odczuwanym poczuciem szczęścia i zadowolenia z własnego życia (well-being). W wyniku przeprowadzonej jednoczynnikowej analizy wariancji Anova uzyskano istotny statystycznie efekt zmiennej: dobrostan psychiczny $(F(2,750)=237,8 ; p<0,001)$. Studenci o niskiej prężności psychicznej wskazują na niski dobrostan psychiczny $(M=43,91)$, w grupie studentów o średniej prężności poziom dobrostanu jest wyższy $(M=50,93)$, a studenci o wysokiej prężności prezentują najwyższy poziom dobrostanu psychicznego $(M=56,91)$. Na podstawie tych wyników możemy sformułować wniosek, że wraz ze wzrostem prężności psychicznej wzrasta poziom dobrostanu psychicznego. Im lepiej studenci potrafią przezwyciężać trudności i sytuacje stresowe życia codziennego, to poziom odczuwanego ogólnego dobrostanu jest wyższy. To istotny wynik, który sugeruje, że studenci pedagogiki charakteryzujący się wysoką prężnością psychiczną mają zasoby osobiste i predyspozycje do pracy nauczycielskiej z dziećmi w wieku przedszkolnym i młodszym szkolnym.

W celu ustalenia, jakie znaczenie ma prężność psychiczna, rozumiana jako zasób wewnętrzny człowieka, dla jego dobrostanu psychicznego, rozumianego jako uogólnione poczucie zadowolenia $\mathrm{z}$ własnego życia, przeprowadzono analizę regresji liniowej. Poszukujemy odpowiedzi na podstawowe pytanie, czy na podstawie poziomu prężności psychicznej możemy przewidzieć jakość dobrostanu psychicznego studentów pedagogiki. Zmienną zależną (wyjaśnianą) jest dobrostan psychiczny, a zmienną wyjaśniającą (predyktorem) jest prężność psychiczna. Zaproponowany model regresji okazał się bardzo dobrze dopasowany do danych $(F(1,751)=701,90$; $p<0,001)$. Na podstawie współczynników regresji można sformułować wniosek, że poziom prężności psychicznej jest silnie i pozytywnie związany z dobrostanem 
psychicznym studentów pedagogiki $(\beta=0,695 ; p<0,001)$. Oznacza to, że wraz ze wzrostem prężności psychicznej wzrasta poziom dobrostanu psychicznego studentów. Testowany model wyjaśnia 48 proc. zmienności wariancji zmiennej zależnej, czyli dobrostanu psychicznego (skoryg. $R^{2}=0,482$ ). W badaniach nad dobrostanem psychicznym, przeprowadzonych wśród 400 studentów pedagogiki, ustalono, że jest on negatywnie związany z poziomem odczuwanego stresu, a pozytywnie - z poziomem zadowolenia ze studiów i wsparciem społecznym ze strony najbliższego otoczenia (Kulawska 2019).

\section{Podsumowanie}

W prezentowanym artykule podjęto próbę ustalenia, jaki jest poziom i korelaty prężności psychicznej studentów kończących studia pedagogiczne, którzy zamierzają podjąć pracę na stanowisku nauczyciela przedszkola lub nauczyciela edukacji wczesnoszkolnej. Badania o charakterze diagnostyczno-eksploracyjnym prowadzone nad prężnością odnoszą się do pomiaru tej właściwości intrapsychicznej, która w znacznym stopniu wyznacza adekwatne funkcjonowanie przyszłego nauczyciela w kontekście indywidualnym i społecznym.

Podsumowując przeprowadzone badania empiryczne, stwierdzamy, że większość studentów pedagogiki, pochodzących z dziewięciu uczelni w Polsce, uzyskała średnie wyniki prężności psychicznej, a co trzeci student - kandydat na nauczyciela wczesnej edukacji - prezentował wysoki poziom prężności psychicznej. Można postawić hipotezę, że w sytuacji przejścia, od czasu ukończeniu studiów aż do pracy nauczycielskiej, grupa studentów charakteryzująca się niską prężnością (18 proc. badanych studentów) posiadała niewystarczające zasoby wewnętrzne lub mechanizmy regulacyjne, aby poradzić sobie z wyzwaniami stojącymi przed nauczycielem w przedszkolu i nauczycielem edukacji wczesnoszkolnej. Prężność psychiczna badanych studentów pozostawała w związku z ich osiągnięciami edukacyjnymi w trakcie studiowania, odczuwanym stresem i dobrostanem psychicznym. Nie wykazano związku między poziomem prężności psychicznej a miejscem zamieszkania i sytuacją finansową studentów.

Analizy statystyczne potwierdziły oczekiwaną hipotezę o negatywnym związku między prężnością a stresem psychologicznym, która jest zgodna z wynikami badań innych autorów (Surzykiewicz i in. 2019; Damasio i in. 2011; Wagnild 2009; Nishi i in. 2010). Ustalono, że studenci deklarujący niższy poziom stresu, mają wyższą prężność psychiczną. Zakładamy, że ci studenci żyją w podobnych warunkach jak studenci deklarujący wysoki poziom stresu, ale ze względu na wysoki poziom prężności potrafią bardziej adekwatnie rozpoznawać bodźce stresowe i uruchamiać mechanizmy psychologiczne odpowiedzialne za optymalne radzenie sobie w trudnych, niejednoznacznych sytuacjach. Tym samym stwierdzamy, że studenci o wymienionych predyspozycjach i zasobach wewnętrznych (wysoki 
poziom prężności i radzenie sobie ze stresem) są pożądanymi kandydatami do zawodu nauczycielskiego.

W badaniach ustalono, że prężność psychiczna jest ważnym i bardzo istotnym predyktorem dobrostanu psychicznego dla studentów pedagogiki. Wykazano silny, pozytywny związek między prężnością a dobrostanem psychicznym. Uzyskane wyniki są zgodne z wynikami badań prowadzonych nie tylko w Polsce, lecz także w innych krajach o zróżnicowanym potencjale kulturowym i w różnych grupach wiekowych (Abiola, Udofia 2011; Baldwin i in. 2011; Callegari i in. 2016b; Damasio i in. 2011; Ogińska-Bulik, 2010; Surzykiewicz i in. 2019; Tugade, Fredrikson 2004; Wagnild 2009). Dobrostan psychiczny, rozumiany jako dynamiczna zmienna będąca wynikiem równowagi między zasobami wewnętrznymi (fizycznymi, psychologicznymi i społecznymi) a oczekiwaniami społecznymi, ma własności ochronne i wspomagające nauczyciela w sytuacjach stresowych i trudnych, które są wpisane w codzienność pracy nauczycielskiej. Dlatego tak ważne jest, aby kandydaci do tego zawodu prezentowali wysoki poziom prężności, który pozostaje w związku z dobrostanem psychicznym studentów. Osoby o wysokiej prężności są mniej podatne/wrażliwe na bodźce stresowe, a jeśli już mają z nimi do czynienia, potrafią bardziej adekwatnie na nie reagować, wyrażając częściej emocje pozytywne niż negatywne, czyli charakteryzują się prawidłową regulacją własnych emocji (Tugade, Fredrickson 2004), potrafią adoptować się do zmiennych warunków zewnętrznych i podejmować racjonalne działanie pomimo niekorzystnych okoliczności.

Ustalona w badaniach pozytywna zależność między prężnością a dobrostanem psychicznym wskazuje na to, że prężność psychiczna może wpływać na szeroko rozumianą jakość życia człowieka. W odniesieniu do studentów pedagogiki teza ta wskazuje na: możliwość rozwijania prężności i kształtowania jej w czasie studiów poprzez wzbudzanie motywacji do pracy nad sobą, budzenie świadomości o własnych emocjach przeżywanych w sytuacjach konfliktowych, traktowanie porażek jako wyzwanie i do stymulowania studentów do pokonywania trudności, a także jako zmiana zachowania w obliczu sytuacji zaskakujących czy trudnych. Jest to możliwe, ponieważ niektóre badania wskazują na to, że prężność psychiczna jako zasób wewnętrzny człowieka może być rozwijana i modyfikowana w ciągu życia (Lundman 2007; Losoi 2013). Wnioski pochodzące z badań mogą stanowić podstawę do modyfikacji programów kształcenia na studiach pedagogicznych, celem uzupełnienia tych aspektów funkcjonowania osobowościowo-społecznego studentów, które wymagają wzmocnienia, poszerzenia lub uzupełnienia, aby usprawnić proces adaptacji kandydatów do zawodu nauczyciela. Te działania mogą przynieść wymierne efekty w zakresie podnoszenia poziomu profesjonalizmu przyszłych nauczycieli wczesnej edukacji. 


\section{Bibliografia}

Abiola T., Udofia O. (2011). Psychometric assessment of the Wagnild and Young's resilience scale in Kano, Nigeria. „BMC Research Notes”, 4 (1), s. 509.

Alex L., Lundman B. (2011). Lack of resilience among very old men and women: A qualitative gender analysis.,,Research and Theory in Nursing Practice”, 25 (4), s. 302-316.

Andrade F.P., Muniz R.M., Lange C., Schwartz E. (2013). Economic and socio-demographic profile of cancer survivors according to degree of resilience. "Text Context Nursing, Florianopolis", April-June, 22 (2), s. 476-484.

Armando A., da Motta N.W., Pinto R.C. i in. (2010). Analysis of resilience and depression scores and their relation to quality of life in ambulatory lung cancer patients undergoing radiation therapy. „Journal of Clinical Oncology”, 28 (15 suppl.).

Baldwin D.R., Jackson III D., Okoh I., Cannon R.L. (2011). Resiliency and optimism: An African American senior citizen's perspective „Journal of Black Psychology”, 37 (1), s. 24-41.

Block J., Kremen A.M. (1996). IQ and ego-resiliency: conceptual and empirical connections and separateness „Journal of Personality and Social Psychology”, 70 (2), s. 349-361.

Bonanno G.A. (2012). Uses and abuses of the resilience construct: Loss, trauma, and health-related adversities. „Social Science and Medicine”, 74, s. 753-756.

Callegari C., Bertu L., Caselli K., Isella C., Lelmini M., Bonalumi C., Ferrario M., Vender S. (2016a). Resilience in older adults: influence of the admission in nursing home and psychopathology. „Neuropsychiatry”, 6 (4), s. 117-123.

Callegari C., Bertu L., Lucano M., Ielmini M., Braggio E., Vender, S. (2016b). Reliability and validity of the Italian version of the 14-item Resilience Scale. "Psychology research and behavior management”, 9, s. 277-284.

Cicchetti D., Rogosch F.A. (1997). The role of self-organization in the promotion of resilience in maltreated children. „Development and psychopathology”, 9 (4), s. $797-815$.

Clarke A., Friede T., Putz R., Ashodown J., Martin S., Blake A., Adi Y., Parkinson J., Flyyn P., Platt S., Stewart-Brown S., Warwick-Edinburgh Mental Well-being Scale (WEMWBS): Validated for teenage school students in England and Scotland. A mixed methods assessment. BMC Public Health, 2011, 11, s. 487.

Cohen M., Baziliansky S., Beny A. (2014). The association of resilience and age in individuals with colorectal cancer: An exporatory cross-sectional study. „Journal of Geriatric Oncology, January", 5 (1), s. 33-39.

Cosco T.D., Kaushal A., Richards M., Kuh D., Stafford M. (2016). Resilience measurement in later life: a systematic review and psychometric analysis. „Health Quality Life Outcomes", 14, s. 16. 
Damásio B.F., Borsa J.C., Da Silva J.P. (2011). 14-item resilience scale (RS-14): psychometric properties of the Brazilian version. „Journal of Nursing Measurement” 19 (3), s. 131-145.

Ebulum G.C., Chidiobi R.U. (2016). Resilience, gender and age as predictors of satisfaction with academic major among university undergraduates. „International Journal of Research in Engineering and Social Sciences", 6 (4), April 2016.

Eley D.S., Cloninger C.R., Walters L., Laurence C., Synnott R., Wilkinson D. (2013). The relationship between resilience and personality traits in doctors: Implications for enhancing wellbeing. „Peer Journal”, November 19. Dostępny na: https://peerj.com/articles/216/?utm_source=TrendMD\&utm_campaign=PeerI_ TrendMD_o\&utm_medium=TrendMD (otwarty: 8.12.2019).

Fredrickson B. (2001). The role of positive emotions in positive psychology: The broaden-and build theory of positive emotions. „American Psychologist”, 56, s. $218-226$.

Garmezy N. (1970). Process and reactive schizophrenia: Some conceptions and issues. „Schizophrenia Bulletin”, 1 (2), s. 30.

Garmezy N. (1971). Vulnerability research and the issue of primary prevention. "American Journal of orthopsychiatry”, 41 (1), s. 101.

Garmezy N., Streitma, S. (1974). Children at risk: The search for the antecedents of schizophrenia: I. Conceptual models and research methods. „Schizophrenia Bulletin", 1 (8), s. 14.

Gheshlagh R.G., Sayehmiri K., Ebadi A., Dalvandi A., Dalvand S., Tabrizi K.N. (2016). Resilience of patients with chronic physical diseases: a systematic review and meta-analysis. „Iranian Red Crescent Medical Journal”, 18 (7).

Gu Q., Day C. (2007). Teachers resilience: a necessary condition for effectiveness. „Teaching and Teacher Education”, 23, s. 1302-1316.

Hofer A., Mizuno Y., Frajo-Apor B., Kemmler G., Suzuki T., Pardeller S., Welte A.S., Sondermann C., Mimura M., Wartelsteiner F., Fleischhacker W.W., Uchida H. (2016). Resilience, internalized stigma, self-esteem, and hopelessness among people with schizophrenia: Cultural comparison in Austria and Japan. „Schizophrenia Research", 171, s. 86-91.

Junik W. (red.) (2011). Resilience. Warszawa: Wydawnictwo Edukacyjne Parpamedia.

Kaczmarek Ł. (2011). Skala Sprężystości Psychicznej-polska adaptacja Ego Resiliency Scale. „Czasopismo Psychologiczne”, nr 17, s. 263-265.

Kaur M., Kaur R. (2017). Resilience as a Predictor of Burnout Behaviour among Secondary School Teachers. „Asian Journal of Research in Social Sciences and Humanities", 7 (2), s. 985-993.

Kulawska E. (2019). Dobrostan psychiczny a poziom odczuwanego stresu i satysfakcji ze studiów $w$ doświadczeniach studentów pedagogiki przedszkolnej $i$ wczesnoszkolnej. „Forum Pedagogiczne”, t. 9, nr 2 cz.2, s. 129-149. 
Leppert K., Gunzelmann T., Schumacher J., Strauss B., Brahler E. (2005). Resilience as a protective personality characteristic in the elderly. "Psychotherapie, Psychosomatik, Medizinishe Psychologie”, 55 (8), s. 365-369.

Losoi H., Turunen S., Waljas M., Helminen M., Ohman J., Julkunen J., Rosti-Otajarvi E. (2013). Psychometric properties of the Finnish version of the Resilience Scale and its short version. „Psychology, Community \& Health”, 2 (1), s. 1-10.

Lundman B., Strandberg G., Eisemann M., Gustafson Y., Brulin C. (2007). Psychometric properties of the Swedish version of the Resilience Scale. "Scandinavian Journal of Caring Sciences”, 21 (2), s. 229-237.

Luthar S.S., Cicchetti D., Becker B. (2000). The construct of resilience: A critical evaluation and guidelines for future work. "Child Development”, 71 (3), s. 543-562.

Masten A.S. (2007). Resilience in developing systems: Progress and promise as the fourth wave rises. „Development and psychopathology”, 19 (3), s. 921-930.

Masten A.S., Garmezy N., Tellegen A., Pellegrini D.S., Larkin K., Larsen A. (1988). Competence and stress in school children: The moderating effects of individual and family qualities. "Journal of Child Psychology and Psychiatry”, 29 (6), s. 745-764.

Mościcka-Teske A., Drabek M., Pyżalski J. (2014). Doświadczanie mobbingu i wrogich zachowań $w$ miejscu pracy a występowanie objawów wypalenia zawodowego u nauczycieli. „Medycyna Pracy”, 65 (4), s. 535-542.

Nishi D., Uehara R., Kondo M., Matsuoka Y. (2010). Reliability and validity of the Japanese version of the Resilience Scale and its short version. „BMC Res Notes” 3 , s. 310.

O’Dougherty-Wright M., Masten A.S., Northwood A., Hubbard J.J. (1997). Long-term effects of massive trauma: Developmental and psychobiological perspectives. W: Rochester Symposium on Developmental Psychopathology, vol. 8: Developmental perspectives on trauma. Cicchetti D., Toth S.L. (red.). NY: University of Rochester Press; Rochester 1997, s. 181-225.

Ogińska-Bulik N. (2009). Osobowość typu D: teoria i praktyka. Łódź: Wydawnictwo WSHE.

Ogińska-Bulik N. (2010a). Potraumatyczny rozwój w chorobie nowotworowej-rola prężności. „Polskie Forum Psychologiczne”, vol. 15, nr 2, s. 125-139.

Ogińska-Bulik N. (2010b). Prężność a jakość życia młodzieży. „Psychologia Jakości Życia”, 1, s. 233-237.

Ogińska-Bulik N. (2011). Rola prężności w zapobieganiu negatywnym skutkom stresu zawodowego. W: Rodzina i praca w warunkach kryzysu. Golińska L., BielawskaBatorowicz E. (red.). Łódź: Wydawnictwo Uniwersytetu Łódzkiego.

Ogińska-Bulik N. (2014). Prężność psychiczna a zadowolenie z życia osób uzależnionych od alkoholu. „Alcoholism and Drug Addiction”, 27 (4), s. 319-324.

Ogińska-Bulik N., Juczyński Z. (2008a). Skala pomiaru prężności-SPP-25. „Nowiny Psychologiczne", 3, s. 39-56.

Ogińska-Bulik N., Juczyński Z. (2008b). Osobowość, stres a zdrowie. Warszawa: Wydawnictwo Difin. 
Ogińska-Bulik N., Kobylarczyk M. (2015). Relation between resiliency and post-traumatic growth in a group of paramedics: the mediating role of coping strategies. "International Journal of Occupational Medicine and Environmental Health", 28 (4), s. 707-19.

Ogińska-Bulik N., Zadworna-Cieślak M. (2014). Rola prężności psychicznej w radzeniu sobie ze stresem związanym z egzaminem maturalnym. „Przegląd Badań Edukacyjnych", 2 (19), s. 7-24.

Ogińska-Bulik N., Zadworna-Cieślak M., Rogala E. (2015). Rola zasobów osobistych $w$ podejmowaniu zachowań zdrowotnych przez osoby $w$ wieku senioralnym. „Problemy Higieny i Epidemiologii”, 96 (3), s. 570-577.

Opora R. (2008). Praktyczne impilkacje wynikające z badań nad odpornościa psychiczna u dzieci i młodzieży. „Studia Gdańskie”, t. 5, s. 97-108.

Ostaszewski K. (2005). Druga strona ryzyka. „Remedium”, 2, s. 1-3.

Patterson J.H., Collins L., Abbott G. (2004). A study of teacher resilience in urban schools. „Journal of Instructional Psychology”, 31 (1), s. 3-11.

Resnick B., Inguito P.L. (2011). The Resilience Scale: Psychometric properties and clinical applicability in older adults. „Archives of Psychiatric Nursing”, 25, s. 11-20.

Richters J.E., Martinez P.E. (1993). Violent communities, family choices, and children's chances: An algorithm for improving the odds. „Development and Psychopathology", 5 (4), s. 609-627.

Rutter M. (1993). Resilience: some conceptual considerations. „Journal of Adolescent Health", 14 (8), s. 626-631.

Southwick S.M., Bonanno G.A., Masten A.S., Panter-Brick C., Yehuda R. (2014). Resilience definitions, theory, and challenges: interdisciplinary perspectives. „European Journal of Psychotraumatology”, vol. 5, issue 1.

Sęk H. (2004). Wypalenie zawodowe nauczycieli. Uwarunkowania i możliwości zapobiegania. W: Wypalenie zawodowe. Przyczyny i zapobiegania. Sęk H. (red.). Warszawa: Wydawnictwo Naukowe PWN.

Stanford B.H. (2001). Reflections of resilient, persevering urban teachers. „Teacher Education Quarterly", 28 (3), s. 75-87.

Surzykiewicz J., Konaszewski K., Wagnild G. (2019). Polish Version of the Resilience Scale (RS-14): A Validity and Reliability Study in Three Samples. „Frontiers in Psychology", 9, s. 2762. Ddostępny na: https://www.frontiersin.org/articles/10.3389/fpsyg.2018.02762/full (otwarty: 30.11.2019).

Szwajca K. (2014). Sprężystość (resilience) i odpowiedzi na doświadczenia urazowe Fascynujacy i trudny obszar badań, „Psychiatria Polska”, 48 (3), s. 563-572.

Tempski P., Santos I.S., Mayer F.B., Enns S.C., Perotta B. i in. (2015). Relationship among Medical Student Resilience, „Educational Environment and Quality of Life", 10 (6).

Terelak J.F., Górska Z., Kowalska M., Martyński M., Zub A. (2007). Nauczyciele. W: Stres zawodowy. Charakterystyka psychologiczna wybranych zawodów stresowych. J. T. Terelak (red.). Warszawa: Wydawnictwo Naukowe UKSW. 
Tucholska S. (2009). Wypalenie zawodowe u nauczycieli. Psychologiczna analiza zjawiska i jego osobowościowych uwarunkowań. Lublin: Wydawnictwo KUL.

Tugade M.M., Fredrickson B.L. (2004). Resilient individuals use positive emotions to bounce back from negative emotional experiences. „Journal of Personality and Social Psychology", 86 (2), s. 320-333.

Uchnast Z. (1997). Prężność osobowa empiryczna typologia i metoda pomiaru. „Roczniki Filozoficzne”, t. XLV, z. 4, s. 27-51.

Wagnild G. (2009). A review of the Resilience Scale. „Journal of Nursing Measurment”, vol. 17, $\mathrm{nr} 2$, s. 105-113.

Wagnild G., Young H. (1993). Development and psychometric. „Journal of Nursing Measurement", 1 (2), s. 165-178.

Wells R.D., Schwebel A. I. (1987). Chronically ill children and their mothers: Predictors of resilience and vulnerability to hospitalization and surgical stress. "Journal of Developmental and Behavioral Pediatrics", 8 (2), s. 83-9.

Williams J.S. (2003). Why great teachers stay. „Educational Leadership”, 6o (8), s. 71-74.

Zubrzycka-Maciąg T. (2013). Psychospołeczne uwarunkowania stresu nauczycielek szkół podstawowych i gimnazjów. Lublin: Wydawnictwo UMCS.

\title{
RESILIENCE, WELL-BEING AND STRESS AMONG STUDENTS OF EDUCATION IN POLAND
}

\begin{abstract}
The aim of this study is to determine the relationships between resilience, well-being and stress among current university students studying pre-school and early-school education. Empirical studies were carried out using the diagnostic survey method among 839 students from nine universities in Poland. Three research tools were used: Resilience Scale -14 Wagnild, WEMWBS (Tennant, Stewart-Brown) and PSS-10 (Cohen, Kamarck, Mermelstein). Statistical analysis of survey data showed that the majority of surveyed students (51.8\%) present an average level of resilience, and whereas a third of students are characterized by a high level of resilience. Based on the hierarchical regression analysis, it was established that resilience is an important predictor of student well-being (corrected $R^{2}=0.482$ ) and stress (corrected $R^{2}=0.223$ ). Therefore, resilience is positively related to the well-being of students and negatively to the stress in everyday life. Resilience can be regarded as an important personal resource of future early education teachers.
\end{abstract}

Keywords: resilience; psychological well-being; stress; pre-school and early-school education student. 